DOI: 10.17707/AgricultForest.61.3.14

\author{
Hossein SADEGHI, Hossein HEIDARI SHARIFABAD, \\ Aidin HAMIDI, Ghorban NOURMOHAMMADI, Hamid MADANI ${ }^{1}$
}

\title{
EFFECTS OF AIR TEMPERATURE DURING SOYBEAN SEED FILLING ON SEED QUALITY
}

\begin{abstract}
SUMMARY
Reproductive development and growth stages of crops are especially important for seed production and affect seed quality. In order to evaluate the effect of planting date via canopy temperature during reproductive growth stages on soybean seed germination and vigor, an experiment was conducted at two locations, experimental farm of seed and plant certification and registration institute in Karaj and experimental farm of agricultural and natural resources center of Moghan, Ardabil, Iran, in 2013. Soybean varieties Williams and $\mathrm{L}_{17}$ were sown the rate of $40 \mathrm{plants} / \mathrm{m}^{2}$ at May 5, June 5, and July 5. The experiment was conducted as a factorial based on randomized complete block design (RCBD) with three replications. Means comparison of three-way interaction made clear that highest percentage of normal seedling (98.3\%) was gained from $\mathrm{L}_{17}$ that was planted at $5^{\text {th }}$ July in Karaj, furthermore the lowest normal seedling percentage (84.7) was obtained from Williams that was planted at $5^{\text {th }}$ May in Moghan. Means comparison results noticed that the highest final abnormal seedling percentage (7.2) was seen in Williams cultivar in Karaj and the lowest rate of it (3.9 percent) was obtained from this cultivar in Moghan. Furthermore the lowest rate of seedling vigor index was obtained from Williams cultivar (89.9) that planted at $5^{\text {th }}$ May in Karaj and $\mathrm{L}_{17}$ cultivar (99.2) that planted at $5^{\text {th }}$ July in Moghan.
\end{abstract}

Keywords: Planting date, reproductive growth stages, normal seedling, abnormal seedling, seedling vigor index.

\section{INTRODUCTION}

Seed quality is a key component of a successful crop production and is needed to ensure adequate plant populations in a range of field conditions. Unfavorable environmental conditions especially high temperature stress during growth and development in the field causes significant losses in yields of Brassica napus L. (Angadi et al. 2000), Lycopersicon esculentum (Mill.) (Sato et

\footnotetext{
1 Hossein Sadeghi, (corresponding author: sadeghi_spcri@yahoo.com), Hossein Heidari Sharifabad, Ghorban Nourmohammadi, Department of Agronomy, Science and Research Branch, Islamic Azad University, Tehran, IRAN; Aidin Hamidi, Seed and Plant Certification and Registration Institute, Karaj, Iran; Hamid Madani, Department of Agronomy, Arak Branch, Islamic Azad University, Arak, IRAN.

Note: The authors declare that they have no conflicts of interest. Authorship Form signed online.
} 
al. 2002), Phaseolus vulgaris (L.) (Shonnard and Gepts, 1994); and Zea mays (L.) (Carlson, 1990).

High temperatures reduce seed yield and quality in growth chamber and phytotron experiments (Egli et al. 2005). Temperatures of $35 / 30^{\circ} \mathrm{C}$ (day/night) (Gibson \& Mullen, 1996) 38/33 ${ }^{\circ} \mathrm{C}$ (Spears et al. 1997), and 38/27 C (Egli et al. 2005) during seed filling reduced germination of seed from several cultivars. Reproductive growth periods ( $R_{1}$ to $R_{7}$ ) of soybean are more sensitive to high temperature. Temperatures that reduced seed quality in controlled environments $\left(32\right.$ to $38^{\circ} \mathrm{C}$ ) could occur in the field during reproductive periods of soybean. Plant reproduction is highly vulnerable to environmental conditions such as temperature and consequently, planet warming may have significant consequences on the reproductive phase with serious implication in agricultural crops. Although pollen tube growth is clearly affected by temperature, little information is available on its effect on the female side and on flower receptivity (Hedhly et al. 2003).

Reproductive development and growth by crops is especially important for human welfare because we depend on crop fruits and seeds, directly and indirectly, for most of our food. Seed production by crops depends on vegetative development and growth, development of pollen and egg, pollination, and fertilization. The final size of individual seeds generally hinges on cell division within the embryo, followed by seed filling and maturation process. Environmental conditions prior to the shift to reproductive development usually affect by influencing photosynthesis per unit of leaf area, canopy development and interception of solar radiation per unit of ground area, and initiation of potential fruiting site; a strong positive correlation between canopy photosynthesis per unit of ground area and seed number exists for most crops.

It has been reported that the environment that helps production of good crop also helps producing good quality seed (Rahman et. al. 2005). The field environment at which the crop is grown and also seeds are harvested regulates the quality of seeds. Although information on the effect of sowing time on yield of soybean cultivars is available (Rahman et al. 2005), the report on the effect of sowing time on seed germination and vigour is scarce in Iran. Therefore, the present research work was undertaken with a view to investigate the effect of sowing dates on germination and vigor of soybean seed. High temperatures during soybean seed development have been reported to have a considerable effect on soybean yields, seed composition, and seed vigor (Wilson, 2004).

When soybean seeds develop under elevated temperature, changes occur in seed oil concentration and in the ratios of individual fatty acids to total fatty acids in the oil (Thomas et al. 2003). Sucrose and the raffinosaccarides, raffinose and stachyose are the main reserve carbohydrates of soybean seeds. Stachyose, sucrose, and other nonreducing soluble carbohydrates are associated with the onset of desiccation tolerance during seed development and with seed storability (Obendorf et al. 1998). Low-stachyose soybeans have been noted to have germination difficulties (Wilson, 2004). Stachyose is associated with membrane 
biogenesis during temperature stress by maintaining the integrity of the cell membranes in seeds (Peterbauer et al. 2001).

Therefore, our objective was to evaluate the effect of planting date via temperature on seed quality of Soybean under the environmental conditions in two areas of Iran.

\section{MATERIAL AND METHODS}

This investigation was conducted at two locations, experimental farm of seed and plant certification and registration institute in Karaj and experimental farm of agricultural and natural resources center of Moghan, Ardabil, Iran, in 2013. Soybean varieties Williams and L17 were sown in six row plots at the rate of 40 plants per $\mathrm{m}^{-2}$ at May 5, June 5, and July 5 in 2013. The experiment was conducted as a factorial based on randomized complete block design (RCBD) with three replications. Normal cultural practices were followed and the plots were hand weeded. Daily maximum and minimum temperatures inside canopies of all experimental units were recorded by placing maximum and minimum thermometers at 4 th node from $\mathrm{R}_{3}$ (the beginning of pods $5 \mathrm{~mm}$ long at one of the four upper most nodes on the main stem with a fully developed leaf) onward. Reproductive growth stages (Fehr et al. 1971) were determined at approximately weekly intervals. Canopy mean maximum, mean minimum and mean average temperatures were calculated for the five reproductive growth stages starting from $R_{3}-R_{4}, R_{4}-R_{5}, R_{5}-R_{6}, R_{6}-R_{7}$ and $R_{7}-R_{8}$. The middle two rows of each plot were harvested at maturity, and seed moisture was measured. A 500g sample of harvested seed from each plot was selected, and germination percentage was evaluated with standard germination test, three replications of 100 seeds were selected from each sample in laboratory, samples were placed between paper as towel method in germinator with 76-86 percent moisture and $25^{\circ} \mathrm{C}$ temperature. After eight days the numbers of normal and abnormal seedling were recorded (ISTA, 2011). Seedling Dry Weight was measured by putting the seedling in oven at $75^{\circ} \mathrm{C}$ as long as 48 hours and seedling vigor index (SVI) was calculated as in Abdul-Baki and Anderson (1973).

The data were statistically analyzed according to SAS, PROC GLM procedure in SAS and means were compared by LSD test at 1 Percent and 5 Percent probability levels.

\section{RESULTS AND DISCUSSION}

According to the results of combined analysis of variance all investigated traits were affected by planting date and soybean cultivars haven't significant effect on studied traits (Table 1).

\section{Normal seedling percentage}

The results of ANOVA showed that normal seedling percentage was affected by planting date, interaction effect of planting date $\times$ cultivar, location $\times$ planting date and location $\times$ planting date $\times$ cultivar $(p \leq 0.05$ and $p \leq 0.01)($ Table 
1). Means comparison of three-way interaction made clear that highest percentage of normal seedling (98.3) was gained from $\mathrm{L}_{17}$ that was planted at $5^{\text {th }}$ July in Karaj, furthermore the lowest normal seedling percentage (84.7) was obtained from Williams that was planted at $5^{\text {th }}$ May in Moghan (Fig. 1).

Table 1. Analysis of variance for studied traits.

\begin{tabular}{lcccc}
\hline \multirow{2}{*}{ Source } & df & \multicolumn{3}{c}{ Mean squares } \\
\cline { 3 - 5 } & & $\begin{array}{c}\text { Normal } \\
\text { seedling }\end{array}$ & $\begin{array}{c}\text { Abnormal } \\
\text { seedling }\end{array}$ & $\begin{array}{c}\text { Seedling } \\
\text { Vigor Index }\end{array}$ \\
\hline Location & 1 & 1.36 & $0.555 \mathrm{~ns}$ & $4254.95^{* *}$ \\
block$(\mathrm{L})$ & 4 & 5.44 & 0.402 & 104.1 \\
Planting date & 2 & $98.86^{* *}$ & $3.392^{* *}$ & $853.9^{* *}$ \\
Cultivar & 1 & 8.02 & $0.001 \mathrm{~ns}$ & 208.99 \\
Planting date $\times$ Cultivar & 2 & $26.36^{* *}$ & $0.607 \mathrm{~ns}$ & 282.77 \\
Location $\times$ Planting date & 2 & $31.86^{* *}$ & $1.824^{* *}$ & $557.91^{*}$ \\
Location $\times$ Cultivar & 1 & $61.36^{* *}$ & $1.834^{*}$ & 0.56 \\
Location $\times$ Planting date $\times$ Cultivar & 2 & $21.02^{*}$ & $0.315 \mathrm{~ns}$ & $681.28^{* *}$ \\
Error & 20 & 4.21 & 0.306 & 112.84 \\
CV\% & & 2.7 & 23.4 & 9.01 \\
\hline
\end{tabular}

$*, * *$ and ns: Significant at the 0.05 and 0.01 probability levels and non-significant, respectively

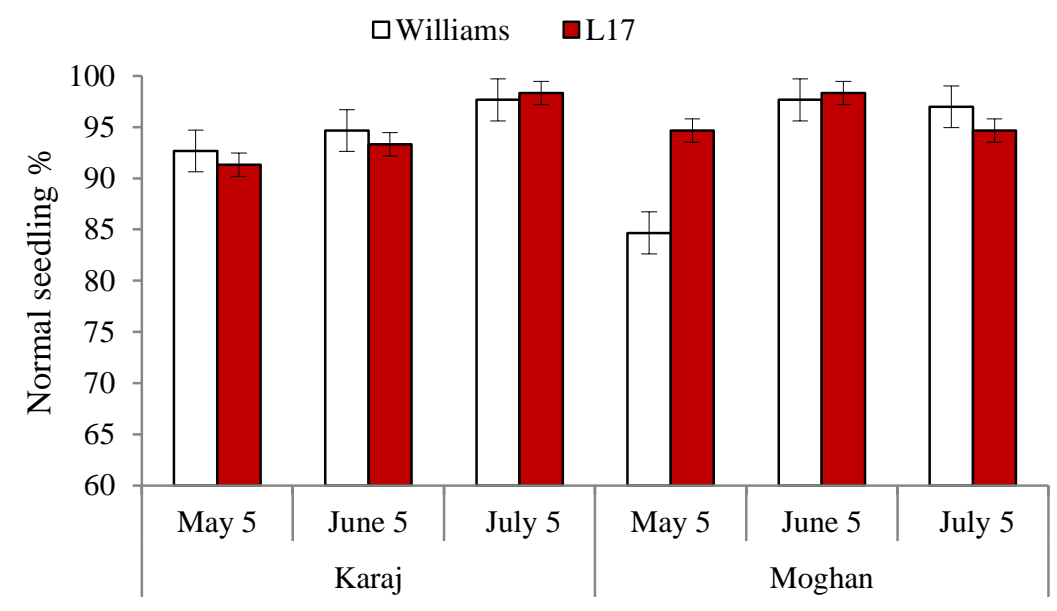

$\mathrm{LSD}=3.69$

Figure 1. Normal seedling percent means comparison of soybean cultivars at different planting dates in two locations. 
Based on the recorded canopy temperature during reproductive stage of soybean, the maximum temperature rate at seed filling stage $\left(R_{5}-R_{6}\right)$ was 28 and $32.1^{\circ} \mathrm{C}$ in Karaj and Moghan respectively for planting date at $5^{\text {th }}$ May and the maximum temperature in this duration was 17 and $24.3^{\circ} \mathrm{C}$ in Karaj and Moghan respectively for planting date at $5^{\text {th }}$ July (Table 2).

Table 2. Canopy temperature $\left({ }^{\circ} \mathrm{C}\right.$ ) in different reproductive stages of soybean.

\begin{tabular}{|c|c|c|c|c|c|c|c|}
\hline \multirow{3}{*}{\multicolumn{2}{|c|}{$\begin{array}{l}\text { Planting } \\
\text { date }\end{array}$}} & \multicolumn{6}{|c|}{ Reproductive stages } \\
\hline & & \multicolumn{2}{|c|}{$\mathrm{R}_{2}-\mathrm{R}_{5}$} & \multicolumn{2}{|c|}{$\mathrm{R}_{5}-\mathrm{R}_{6}$} & \multicolumn{2}{|c|}{$\mathrm{R}_{6}-\mathrm{R}_{7}$} \\
\hline & & Karaj & Moghan & Karaj & Moghan & Karaj & Moghan \\
\hline $5^{\text {th }}$ & Max & 30.5 & 32.9 & 28 & 32.1 & 24.1 & 28.6 \\
\hline May & Min & 16.9 & 19.7 & 16.1 & 17.6 & 13.3 & 18 \\
\hline $5^{\text {th }}$ & Max & 29 & 30.5 & 25.5 & 26.4 & 19.9 & 25.4 \\
\hline June & Min & 17 & 17 & 14 & 9 & 10.5 & 8.8 \\
\hline $5^{\text {th }}$ & Max & 24.1 & 29.3 & 17 & 24.3 & 14.1 & 19 \\
\hline July & Min & 12 & 13 & 8.2 & 13 & 6.3 & 6.3 \\
\hline
\end{tabular}

Since at $5^{\text {th }}$ May planting date, the sensitive reproductive stages growth of soybean is faced with higher temperature, so it is deduced that high temperature caused physiological changes in seed and finally decrement of normal seedling percent. Also because of lower temperature at reproductive stages in Karaj location, the highest normal seedling percent was observed from $5^{\text {th }}$ July planting date. Furthermore in order to precipitation at the physiological maturity and consequently delay of harvesting, the seed deterioration is occurred. Khan et al. (2011) reported that soybean seed germination was negatively affected by average canopy temperature during growth stage of seed beginning to full-seed formation $\left(\mathrm{R}_{5}-\mathrm{R}_{6}\right)$. Gibson \& Mullen (1996) found similar results and stated that high temperature lowered germination and vigor when applied during the first 10 to 30 days of seed development period. Germination and vigor of seed were consistently lowered as days of the high temperature accumulated throughout the seed-filling period. Zanakis et al. (1994) stated that germination decreased 28 Percent, and vigor declined (38 Percent), when the plants were exposed to high temperature stress $\left(35-43^{\mathrm{oC}}\right)$ during seed development and maturation periods. Egli et al. (2005) showed that standard germination and accelerated-aging germination (AA) decreased as mean maximum temperature during seed filling increased.

\section{Abnormal seedling percentage}

Planting date interaction effect with location for abnormal seedling percentage was statistically significant (Table 1). Mean comparison of planting date $\times$ location interaction indicated that the highest abnormal seedling percent (9.25) was related to the $5^{\text {th }}$ May in Moghan that was correlated with the high temperature in reproductive stages $\left(\mathrm{R}_{2}-\mathrm{R}_{7}\right)$ and lowest of it (1.9) obtained from $5^{\text {th }}$ June (Fig. 2). 


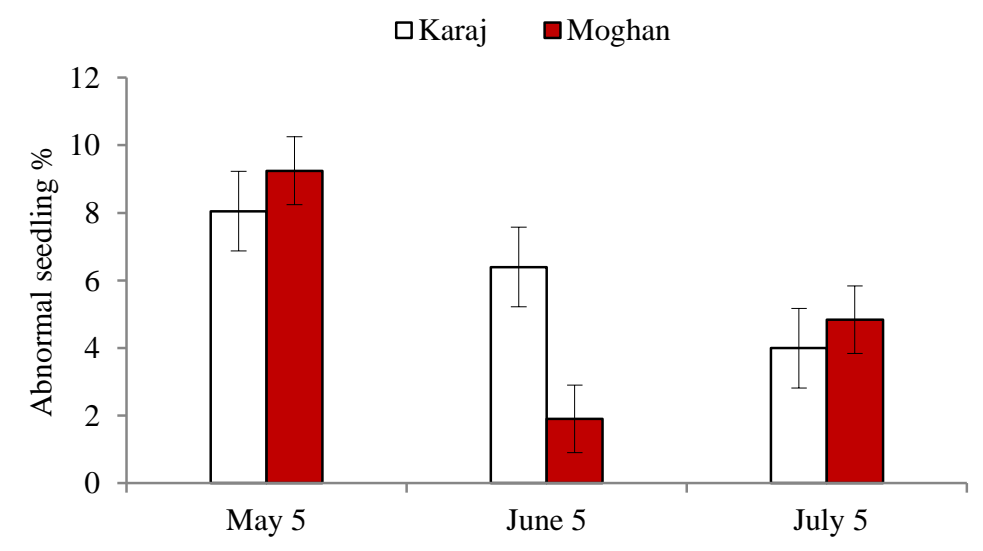

$\mathrm{LSD}=3.03$

Fig. 2. Abnormal seedling percentage at different planting dates in two locations.

Abnormal seedling percentage was affected by interaction effect of planting date $\times$ cultivar (table 1 ). Means comparison results noticed that the highest final abnormal seedling percentage (7.2) was seen in Williams cultivar in Karaj and the lowest rate of it (3.9) was obtained from this cultivar in Moghan (Fig. 3).

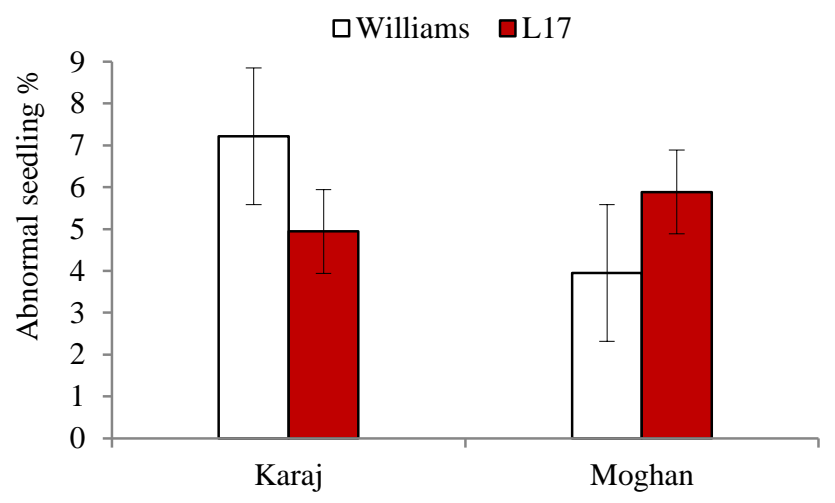

$$
\mathrm{LSD}=2.47
$$

Fig. 3. Abnormal seedling percentage at different planting dates in two locations.

Seed development begins with a period of cell division when all seed structures are formed, followed by accumulation of storage reserves until physiological maturity when growth stops and the seed is ready to germinate. High temperatures during seed filling frequently disrupt normal seed development, which increases the proportion of seeds that are shriveled and abnormal (Egli, 1995). Khan et al. (2011) reported that mean minimum canopy 
temperature $\left(14-25^{\circ} \mathrm{C}\right.$ ) during $\mathrm{R}_{6}$ to $\mathrm{R}_{7}$ growth stage exerts a slight positive effect on protein content. Maximum canopy temperature in the range of $30-37^{\circ} \mathrm{C}$ during growth stages of $R_{4}$ to $R_{5}$ and $R_{5}$ to $R_{6}$ has negatively affected the protein and oil contents of soybean. Thomas et al. (2003) reported that protein content of soybean increased as the growth temperature increased up to $40 / 30^{\circ} \mathrm{C}$ and then decreased dramatically.

\section{Seedling vigor index}

Three-way interaction of location $\times$ planting date $\times$ cultivar for seedling vigor index was statistically significant $(\mathrm{p} \leq 0.01)$ (Table 1$)$. It was noticed that the highest seedling vigor index was related to $\mathrm{L}_{17}$ cultivar that planted at $5^{\text {th }} \mathrm{July}$ (142.7) and $5^{\text {th }}$ June (138.1) in Karaj and Moghan, respectively. Furthermore, the lowest rate of it was obtained from Williams cultivar (89.9) that planted at $5^{\text {th }}$ May in Karaj and $\mathrm{L}_{17}$ cultivar (99.2) that planted at $5^{\text {th }}$ July in Moghan (fig. 4).

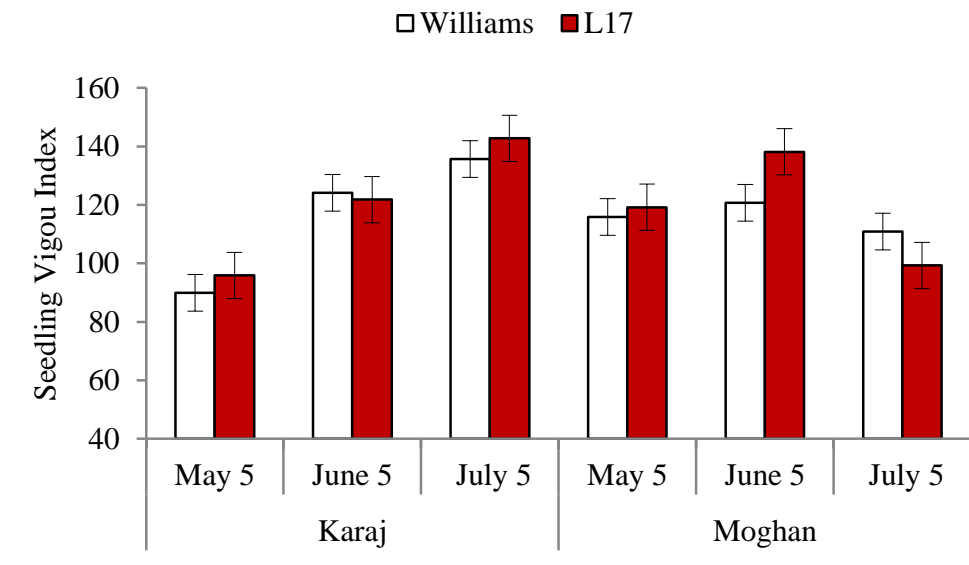

$\mathrm{LSD}=18.09$

Fig. 4. Seedling vigor index of soybean cultivars at different planting dates in two locations.

It was reported that Average maximum canopy temperature (31-37 $\mathrm{C}$ ) negatively affected the seedling dry weight and field emergence of soybean at growth stage of full bloom to seed initiation $\left(R_{4}\right.$ to $\left.R_{5}\right)$. This decrease in field emergence rate during $R_{5}$ to $R_{6}$ growth stage may be due to increase in diurnal temperatures which expose the developing seed to high temperature resulting in reduced seed growth rate and duration (Dornbos and Mullen, 1991). Spears et al. (1997) interrelated maximum daily temperature during seed maturation with seed germination and field emergence, and found that plants matured during hot, dry conditions produced seeds of inferior quality.

Prasad et al. (1999) found that vigor reduced in peanut plants when exposed to high temperature stress during the last 40 days of seed growth. Mean 
maximum canopy temperature during $\mathrm{R}_{4}$ to $\mathrm{R}_{5}$ growth stage decreased seedling dry weight of soybean. The decrease in seedling dry weight demonstrates that soybean is sensitive to high temperature $\left(31\right.$ to $\left.37^{\circ} \mathrm{C}\right)$ during these growth periods. Keigley and Mullen (1986) stated that high temperature lowered germination and vigor, when applied during the first 10 to 30 days of seed development. The linear relationship of germination and seedling dry weight with increase in high temperature explains most of the variation in seed germination and seedling vigor. The previous studies found that the duration of seed growth in soybean was relatively insensitive to increases in day temperature over a range of 20 to $30^{\circ} \mathrm{C}$, but was reduced when day temperatures were $33^{\circ} \mathrm{C}$ or greater (Dornbos and Mullen, 1991). Seedling dry weight decreased and electrical conductivity increased with maximum canopy temperature $\left(31-37^{\circ} \mathrm{C}\right)$ during $R_{3}$ to $R_{4}$ and $R_{4}$ to $R_{5}$ growth stages.

Seed development begins with a period of cell division when all seed structures are formed, followed by accumulation of storage reserves until physiological maturity, when growth stops and the seed is ready to germinate (Egli, 1998). High temperatures during seed filling frequently disrupt normal seed development, which increases the proportion of seeds that are shriveled and abnormal. The quality of these seeds is usually lower, sometimes much lower, than that of normal seeds (Spears et al. 1997). Delaying planting so that seed filling occurs later in the growing season when temperatures are lower will reduce the chances of high temperature injury and should result in the production of higher quality soybean seed. Standard germination was always less sensitive to high temperature stress than seed vigor, suggesting that seed lots produced in high temperature environments could have acceptable or high levels of standard germination, but low vigor levels. Without a vigor test, such seed could lead to stand failure when planted in less than ideal conditions. Evaluation of long-term temperature records suggests that temperature will, in some soybean production areas, routinely reduce seed vigor of some cultivars, although more information on cultivar differences and growth stage specific effects is needed to precisely predict potential damage. Problems resulting from high temperature can probably be alleviated with proper management practices, but the extent of cultivar susceptibility will determine how often changes in management practices are justified.

\section{CONCLUSIONS}

These results elucidated that because of encountering the pod set and grain filling stages with higher temperature, the lowest normal seedling percentage was obtained from Williams that was planted at $5^{\text {th }}$ May in Moghan and the highest final abnormal seedling percentage was seen in Williams cultivar in Karaj and the lowest rate of it was obtained from this cultivar in Moghan. So, in order to prohibition of this problem occurrence, it is suggest that soybean doesn't planted in May and it should be postponed until the mid of June. 


\section{ACKNOWLEDGEMENTS}

Sincere gratitude goes to Seed and Plant Certification and Registration Institute of Iran and Agricultural and Natural Research Center of Ardabil for providing plant materials, experimental sites, and technical assistance.

\section{REFERENCES}

Abdul Baki, A. A. \& Anderson, J. D. (1973): Vigor determination in soybean by multiple criteria. Crop Science., 13: 630-633.

Angadi, S. V. Cutforth, H. W. Miller, P. R. McConkey, B. G. Entz, M. H. Brandt, S. A. \& Volkmar, K. M. (2000): Response of three Brassica species to high temperature stress during reproductive growth. Canadian Journal of Plant Science., 80: 693-701.

Carlson, R. E. (1990): Heat stress, plant-available soil moisture, and corn yields in Iowa: a short-and long-term view. Journal of Production Agriculture., 3: 293297.

Dornbos, D. L. J. \& Mullen, R. E. (1991): Influence of stress during soybean seed filling on seed weight, germination and seedling growth rate. Canadian Journal of Plant Science., 71: 373-383.

Egli, D. B. \& TeKrony, D. M. (1995): Soybean seed germination, vigor and field emergence. Seed Science and Technology., 23: 595-607.

Egli, D. B. TeKrony, D. M. \& Spears, J. F. (2005) High temperature stress and soybean seed quality: Stage of seed development. Seed Technology., 33: 345352.

Fehr, W. R. Caviness, C. E. Burmood, D.T. \& Pennington, J. S. (1971): Stage of development descriptions for soybeans, Glycine Max (L.) merrill. Crop Science., 11: 929- 931.

Gibson, L. R. \& Mullen, R. E. (1996): Soybean seed quality reductions by high day and night temperature. Crop Science., 36:1615-1619.

Hedhly, A. Hormaza, J. I. Herrero, M. (2003): The effect of temperature on stigmatic receptivity in Sweet Cherry (Prunus avium L.). Plant Cell and Environment., 26: 1673-1680.

ISTA. (2011): Proceeding of International Rules for Seed Testing. International Seed Testing Association (ISTA). Seed Science and Technology., 27: Supplement.

Keigly, P. J. \& Mullen, R. E. (1986): Changes in soybean seed quality from high temperature during seed fill and maturation. Crop Science., 26: 1212-1216.

Khan, A. Z. Khan, H. Ghoneim, A. Khan, R. \& Ebid, A. (2007): Seed quality and vigor of soybean as influenced by planting date, density and cultivar under temperature environment. International Journal of Agricultural Research., 2(4): 368-376.

Khan, A. Z. Shah, P. Khan, H. Nigar, S. Perveen, S. Shah, M. K. Amanullah Khalil, S. K. Munir, S. \& Zubair, M. (2011): Seed quality and vigor of soybean cultivars as influenced by canopy temperature. Pakistan Journal of Botany., 43: 643-648.

Obendorf, R. L. Horbowicz, M. Dickerman, A. M. Brenac, P. \& Smith, M. E. (1998): Soluble oligosaccharides and galactosyl cyclitols in maturing soybean seeds in planta and in vitro. Crop Science., 38: 78-84. 
Peterbauer, T. Lahuta, L. B. Blöchl, A. Mucha, J. Jones, D. A. Hedley, C. L. Gòrecki, R. J. \& Richter A. (2001): Analysis of the Raffinose family oligosaccharide pathway in pea seeds with contrasting carbohydrate composition. Plant Physiology., 127: 1764-1772.

Prasad, P. V. V. Craufurd, P. Q. \& Summerfield, R. J. (1999): Sensitivity of peanut to timing of heat stress during reproductive development. Crop Science., 39: 1352-1357.

Rahman, M. M. Hampton, J. G. \& Hill, M. J. (2005): The effect of time of sowing on soybean seed quality. Seed Science and Technology., 33: 687-697.

Sato, S. Peet, M. M. Thomas, J. F. (2002): Determining critical pre and post anthesis periods and physiological processes in Lycopersicon esculentum Mill., exposed to moderately elevated temperatures. Journal of Experimental Botany., 53: 1187-1195.

Shonnard, G. C. \& Gepts, P. (1994): Genetics of heat tolerance during reproductive development in common bean. Crop Science., 34: 1168-1175.

Spears, J. F. TeKrony, D. M. \& Egli, D. B. (1997): Temperature during seed filling and soybean seed germination and vigor. Seed Science and Technology., 25: 233-244.

Thomas, J. M. G. Boote, K. J. Allen, L. H. Gallo-Meagher, J. R. M. \& Davis, J. M. (2003): Elevated temperature and carbon dioxide effects on soybean seed composition and transcript abundance. Crop Science., 43: 1548-1557.

Thuzar, M. Puteh, A. B. Abdullah, N. A. P. Lassim, M. B. M. \& Kamaruzaman, J. (2010): The Effects of Temperature Stress on the Quality and Yield of Soya Bean [(Glycine $\max$ L.) Merrill.]. Journal of Agricultural Sciences., 2(1): 172179.

Wilson, R. F. (2004): Seed composition. p. 521-677. In Boerma, H. R. \& Specht, J. E. (ed.) Soybeans: Improvement, production, and uses. $3^{\text {rd }}$ ed. ASA, CSSA, SSSA, Madison, WI.

Zanakis, G. N. Ellis, R. H. \& Summerfield, R. J. (1994): A comparison of changes in vigor among three genotypes of soybean (Glycine max) during seed development and maturation in three temperature regimes. Experimental Agricultural., 30: 157-170 